\title{
THE USE OF A DEWAR FLASK IN MEASUREMENTS OF HEATS OF NEUTRALIZATION
}

BY J. HOWARD MATHEWS AND A. F. O. GERMANN

Many attempts have been made to devise a simple laboratory method for the accurate determination of heats of neutralization. The method in most common use is cumbersome, and has some other very serious objections. The chief of these is the necessity of removing one of the reacting liquids from its calorimeter and pouring into the other; an operation which introduces a temperature change the magnitude of which cannot be estimated, and for which consequently no correction can be applied. Of importance also is the fact that two thermometers are required, which may introduce considerable error if they have not been accurately compared and standardized against each other.

To overcome these objections various devices have been tried. Thus Julius Thomsen placed one calorimeter above the other and mixed the liquids after temperature equilibrium had been reached, by allowing the upper liquid to flow into the lower. Nernst tried to remove the necessity of the second thermometer and at the same time insure temperature equilibrium before mixing by immersing the acid, contained in a large test tube, in the alkali, and breaking the tube when temperature equilibrium had been reached. Kahlenberg has used a somewhat similar device in that he replaced the test tube by a thin glass flask open at both ends, over the bottom of which he placed paraffined paper. The latter could be broken without difficulty and was easily replaced. Rubber membranes have also been used. Still others have used a collapsible cup for holding one of the reacting liquids until temperature equilibrium was attained.

In both the Thomsen and Berthelot methods, and their various modifications, the correction for radiation is often large and necessarily of somewhat uncertain value. Furthermore, heat radiation is undesirable because it also accentuates 
the error due to thermometric lag. ${ }^{1}$ The adiabatic method devised by Richards and Rowe, ${ }^{2}$ is of course, the best method so far devised for the determination of heats of neutralization where very accurate results are required.

The primary object of the present investigation was to devise an apparatus of simple construction which would be free from the more prominent sources of error in the Berthelot and Thomsen methods. Preliminary experiments in which two Dewar cylinders replaced the customary calorimeter and concentric polished cylinders of the Thomsen method or the calorimeter and surrounding water jacket of the Berthelot method showed a very great improvement, as the radiation correction became very small because of the superior insulation afforded by the Dewar flasks. This makes the radiation correction more certain in value and reduces the error due to thermometric lag, although it does not entirely eliminate it.

We then conceived the idea of replacing the large and cumbersome calorimeter in common use by a Dewar flask, and of using a cylindrical tube of thin glass whose lower end was closed by a rubber septum to separate the acid from the base; and, further, of determining the heats of neutralization of several acids with sodium hydroxide at different concentrations to ascertain the general applicability of the method.

A silvered Dewar flask (see figure) of about 600 cc capacity constitutes the calorimeter. The glass cell $\mathrm{B}$ has a capacity of about $250 \mathrm{cc}$, and fits loosely into the flask. At the bottom is a flange over which a small piece of dentist's rubber dam may be tightly drawn, and held by a rubber band. The cell $B$ is attached to a brass sleeve and eccentric, which gives it a vertical motion, guided by a central modified Witt stirring rod $\mathrm{C}$, whose motion is rotary. By th's means the two solutions, both within and without the cell $\mathrm{B}$, are well stirred. The flask is closed by a cork stopper containing two holes; one in the center to allow the passage of the central stirring

${ }^{1}$ Richardson, Henderson and Forbes: Proc. Am. Acad., 4I, I; Zeit. phys. Chem., 52, 55 I (1905).

${ }^{2}$ Zeit. phys. Chem., 64, I87 (1908). 
rod and the pitman attached to the crank, and the other at one side for the entrance of the thermometer. The latter dips into the liquid contained in the cel: $B$. The cork is covered with bright tinfoil to reduce radiation.

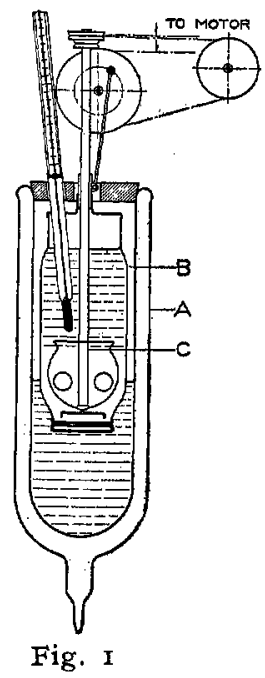

The thermometers used were a Beckmann and two others not of the differential type. One of the latter was graduated to twentieths of a degree, and read from $15^{\circ}-30^{\circ}$; and the other read from $18^{\circ}-25^{\circ}$ and was graduated to hundredths of a degree, as was also the Beckmann. The instruments were all of Goetze's make and of the best grade. They were not standardized for this work, however, since we had in mind only the testing out of the method to ascertain its adaptability to general laboratory practice. Therefore the values here given are in no wise to be interpreted as a revision of Thomsen's values. Nevertheless we believe that we have demonstrated that by the method here described a high degree of accuracy may be attained.

The acid solutions were made up in carbon dioxide free water, and were carefully checked against each other. Half normal hydrochloric acid, standardized gravimetrically by precipitation as silver chloride, was used as the starting point. 
The sodium hydroxide was Merck's "from alcohol," and was freed from carbonate by making up first a I : I solution, in which sodium carbonate is very insoluble, filtering, and making up to the required strength. For the half normal solutions sodium hydroxide prepared from metallic sodium, by allowing to stand in a platinum dish over water in a desiccator protected with a soda-lime tube, was also used. The thermal data obtained by the use of the solutions prepared in these two ways checked so closely that the Merck product, purified as described, was used for the other concentrations.

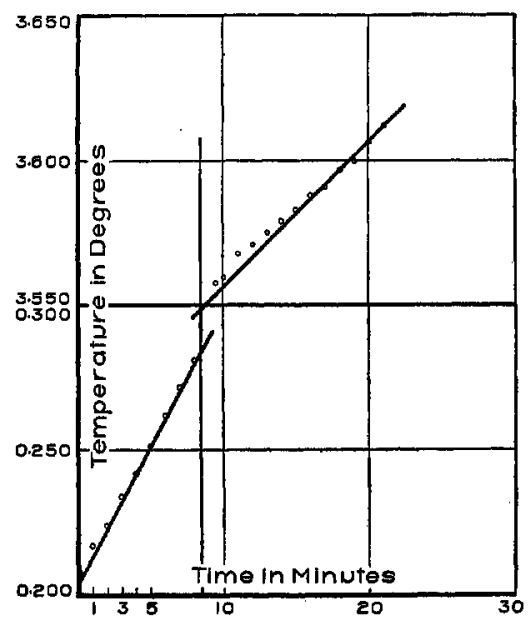

Fig. 2

(Curve I)

The initial temperature of the determinations for all but the twice normal solutions was $18^{\circ}$. For twice normal sulphuric acid the initial temperature was about $15^{\circ}$, and for the other twice normal solutions about $16^{\circ}$. The solutions after being brought to the desired temperature were measured from a $200 \mathrm{cc}$ pipette, the exact capacity of which had been determined, and the excess of the acid or alkali was ascertained after each experiment by titration, tusing phenolphthalein as an indicator. The motor was run at such a rate that the cell $B$ plunged up and down about once per second; while the 
central stirring rod was geared so as to make about four or five revolutions per second. The initial temperature of the base, which was always placed in the cell $\mathrm{B}$, was always a little higher than that of the acid. This gave an opportunity to determine when temperature equilibrium was established, for the thermometer, which was placed in $\mathrm{B}$, at first showed a slow drop in temperature, came to a minimum, and then finally began to rise again due to communication of heat from without the apparatus. The minimum reading showed temperature equilibrium, and this was always reached in less than

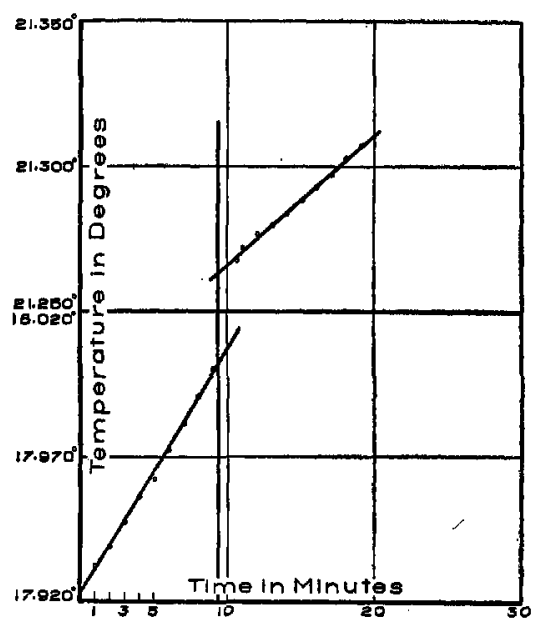

Fig. 3

(Curve II)

five minutes. Temperature readings were made at intervals of one minute. When the thermometer seemed to be rising regularly the stirring rod, which was provided with two sharp copper points at the base, was lowered without interrupting the stirring, so that the points, coming in contact with the tightly stretched membrane, tore the latter and allowed the solutions to mix. At the same time the flask was raised, thus plunging the cell with its contents into it to such a depth that the solution could flow over the top of the cell $B$ and thus insure thorough mixing in the least possible 
time. The time at which the mercury thread of the thermometer began to rise was noted and taken as the time of mixing. One minute was required for the thermometer to register the total rise in the case of the normal, half normal and twice normal solutions; thirty seconds for the quarter normal. The temperatures were plotted against the time, and by a slight extrapolation the exact temperature of the solution before and after mixing was found. It was found that about five minutes were necessary for the glass flask, etc., to assume the temperature of the solution; hence only those temperatures should be considered which were taken after the expiration of this time, $i . e$., the time required for temperature equilibrium.

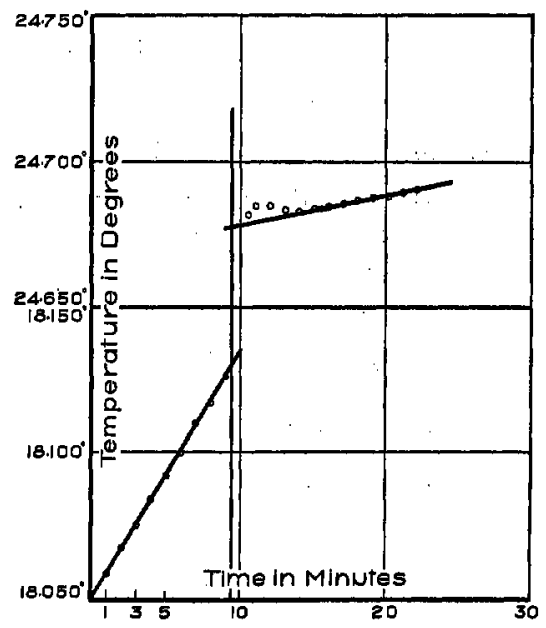

Fig. 4

(Curve III)

The water equivalent of the apparatus could not be determined directly, but was found indirectly by allowing a reaction of known thermal value to take place in it, and from this calculating the water equivalent. The reaction employed was the neutralization of half normal hydrochloric acid by sodium hydroxide. The heat of neutralization is given by Julius Thomsen in this case as 13,740 calories at 
$18^{\circ}$. The mean of two concordant determinations was taken as the true value, and was found to be 23.2 grams. The data and computations appear in the following table:

I. To Determine the Heat Capacity of the Apparatus, as ExPRESSED IN TERMS OF THE WaTER EOUIVALENT

Volume of measuring pipette

Weight of $\mathrm{N} / 4$ solution formed

Specific heat of $\mathrm{N} / 4 \mathrm{FCl}$ solution (Thomsen)

Rise of temperature (from Curve I)

Final temperature

Initial temperature

Rise in temperature during experiment

"Heat Capacity" of the solution:

I $98.4 \mathrm{cc}$

402.7 grams

0.980

$3 \cdot 549^{\circ}$

$0.286^{\circ}$

$3.263^{\circ}$

$$
402.7 \times 0.980=394.64 \text { grams }
$$

Total heat taken up by the solution:

$$
394.64 \times 3.263=1287.7 \mathrm{cal}
$$

One gram equivalent of sodium hydroxide (at a dilution of $\mathrm{N} / 2$ ) should liberate 13,740 cals. (Thomsen).

Then $\mathrm{r} 98.4 \mathrm{cc}$ of $\mathrm{N} / 2$ solution should liberate:

$$
\frac{198.4 \times I 3,740}{2000}=\mathrm{I}_{3} 63 \text { cals. }
$$

The difference divided by the rise,

$$
\frac{1363-1287.7}{3.263}=23.07
$$

is the water equivalent of the apparatus.

By a similar calculation we obtain from Curve II a rise of $3.26 \mathrm{I}^{\circ}$, and a water equivalent for the apparatus of 23.33 grams. The mean of these two values is 23.2 , and differs from each individual determination by but 0.6 percent. This reduces to a negligible quantity in the final calculations of heats of neutralization, viz., o.I percent in the case of the half normal solutions, 0.025 percent for the normal ones, and 0.005 percent for the twice normal ones. 
II. Method of Calculation of Heat of Neutralization. (NEUTRALIzation OF NORMal Hydrochloric ACID WITH SOdIUM HYDROXIDE).

Temperature rise (from Curve III)

Final temperature

Initial temperature

$24.678^{\circ}$
I 8.130

Total rise in temperature during expt. Specific heat of $\mathrm{N} / 2 \mathrm{NaCl}$ solution (Thomsen) Weight of $\mathrm{NaCl}$ solution formed Water equivalent of $\mathrm{NaCl}$ solution formed: $408.83 \times 0.964=394$, I I grams.

Total water equivalent

Total heat liberated $394 . \mathrm{II}+23.2=417.31 \mathrm{grams}$ $417.31 \times 6.548=2732.6 \mathrm{cal}$

Volume of sodium hydroxide actually neutralized I98. I $\mathrm{cc}$ Iooo cc (containing one gram equivalent) would the refore liberate

$$
\frac{2732 \times 1000}{198.1}=\text { I } 3,793 \text { calories. }
$$

The complete data for the determinations made on the four concentrations appear in the following table.

The results obtained for half normal solutions are somewhat lower than those given by Thomsen (Thermochemische Untersuchungsmethoden Vol. I) except in the case of nitric acid. The molecular heats of neutralization found at different dilutions exhibit little regularity of change; in the case of hydrochloric acid the value increases with the concentration; for nitric acid the value remains more nearly constant; for sulphuric acid it increases with the concentration; and for acetic acid the value diminishes from $13.2+$ calories for fourth and half normal solutions to I2.9 + calories for twice normal solutions. Greater dilution than half normal seems to have little effect on the heat of neutralization.

As shown by the curves, the absorption of heat when working at even $10^{\circ}-\mathrm{I}_{4}^{\circ}$ below room temperature is very small, amounting to less than $I / 100^{\circ}$ per minute. All of these determinations were made under unfavorable conditions, as they were all made in July when the temperature of the room was generally about $30^{\circ}$. Under ordinary laboratory conditions much better results could undoubtedly be obtained. 


\begin{tabular}{|c|c|c|}
\hline Strength of acid used & $\begin{array}{l}\text { Heat of neutralization } \\
\text { (in calories) }\end{array}$ & Average value \\
\hline $\begin{array}{l}\mathrm{N} / 4 \mathrm{HCl} \\
\mathrm{N} / 4 \mathrm{HCl}\end{array}$ & $\begin{array}{l}\text { I } 3,508 \\
\text { I } 3,565\end{array}$ & r 3,536 \\
\hline $\mathrm{N} / 2 \mathrm{HCl}$ & - & $(13,740)^{1}$ \\
\hline $\begin{array}{ll}\mathrm{N} & \mathrm{HCl} \\
\mathrm{N} & \mathrm{HCl}\end{array}$ & $\begin{array}{l}\text { I } 3,79 \text { I } \\
\text { I } 3,785\end{array}$ & I 3,788 \\
\hline $\begin{array}{ll}2 & \mathrm{~N} \mathrm{HCl} \\
2 & \mathrm{~N} \mathrm{HCl}\end{array}$ & $\begin{array}{l}\text { I } 3,923 \\
\text { I } 3,906\end{array}$ & 13,915 \\
\hline $\begin{array}{l}\mathrm{N} / 4 \mathrm{HNO}_{3} \\
\mathrm{~N} / 4 \mathrm{HNO}_{3}\end{array}$ & $\begin{array}{l}13,536 \\
13,56 \mathrm{I}\end{array}$ & I 3,548 \\
\hline $\begin{array}{l}\mathrm{N} / 2 \mathrm{HNO}_{3} \\
\mathrm{~N} / 2 \mathrm{HNO}_{3}\end{array}$ & $\begin{array}{l}\text { I } 3,648 \\
\text { 1 } 3,647\end{array}$ & I 3,647 \\
\hline $\begin{array}{ll}\mathrm{N} & \mathrm{HNO}_{3} \\
\mathrm{~N} & \mathrm{HNO}_{3}\end{array}$ & $\begin{array}{l}\text { I } 3,6 \text { I } 2 \\
\text { I } 3,6 \text { I } 6\end{array}$ & $\mathrm{I}_{3}, 6 \mathrm{I}_{4}$ \\
\hline $\begin{array}{ll}2 & \mathrm{~N} \mathrm{HNO}_{3} \\
2 & \mathrm{~N} \mathrm{HNO}_{3} \\
2 & \mathrm{~N} \mathrm{HNO}_{3}\end{array}$ & $\begin{array}{l}\text { I } 3,649 \\
13,633 \\
13,627\end{array}$ & $\mathrm{I} 3,636$ \\
\hline $\begin{array}{l}\mathrm{N} / 4 \mathrm{H}_{2} \mathrm{SO}_{4} \\
\mathrm{~N} / 4 \mathrm{H}_{2} \mathrm{SO}_{4}\end{array}$ & $\begin{array}{l}\text { I } 5,370 \\
\text { I } 5,353\end{array}$ & $\mathrm{I} 5,36 \mathrm{I}$ \\
\hline $\begin{array}{l}\mathrm{N} / 2 \mathrm{H}_{2} \mathrm{SO}_{4} \\
\mathrm{~N} / 2 \mathrm{H}_{2} \mathrm{SO}_{4}\end{array}$ & $\begin{array}{l}\text { I } 5,585 \\
\text { I } 5,593\end{array}$ & I 5,589 \\
\hline $\begin{array}{ll}\mathrm{N} & \mathrm{H}_{2} \mathrm{SO}_{4} \\
\mathrm{~N} & \mathrm{H}_{2} \mathrm{SO}_{4}\end{array}$ & $\begin{array}{l}\text { I } 5,674 \\
\text { I } 5,667\end{array}$ & I 5,670 \\
\hline $\begin{array}{ll}2 & \mathrm{~N} \mathrm{H}_{2} \mathrm{SO}_{4} \\
2 & \mathrm{~N} \mathrm{H}_{2} \mathrm{SO}_{4}\end{array}$ & $\begin{array}{l}\text { I } 5,8 \text { I } 7 \\
\text { I } 5,8 \text { IO }\end{array}$ & I 5,8 I 3 \\
\hline $\begin{array}{l}\mathrm{N} / 4 \mathrm{CH}_{3} \mathrm{COOH} \\
\mathrm{N} / 4 \mathrm{CH}_{3} \mathrm{COOH}\end{array}$ & $\begin{array}{l}\text { I } 3,219 \\
\text { I } 3,244\end{array}$ & $\mathrm{I} 3,23 \mathrm{I}$ \\
\hline $\begin{array}{ll}\mathrm{N} / 2 & \mathrm{CH}_{3} \mathrm{COOH} \\
\mathrm{N} / 2 & \mathrm{CH}_{3} \mathrm{COOH} \\
\mathrm{N} / 2 & \mathrm{CH}_{3} \mathrm{COOH}\end{array}$ & $\begin{array}{l}\text { I } 3,23 \text { I } \\
\text { I } 3,237 \\
\text { I } 3,233\end{array}$ & I 3,234 \\
\hline $\begin{array}{ll}\mathrm{N} & \mathrm{CH}_{3} \mathrm{COOH} \\
\mathrm{N} & \mathrm{CH}_{3} \mathrm{COOH}\end{array}$ & $\begin{array}{l}\text { I } 3, \text { I } 75 \\
\text { I } 3,162\end{array}$ & $\mathrm{I} 3, \mathrm{I} 68$ \\
\hline $\begin{array}{ll}2 & \mathrm{~N} \mathrm{CH}_{3} \mathrm{COOH} \\
2 & \mathrm{~N} \mathrm{CH} \\
2 & \mathrm{COOH} \\
2 & \mathrm{CH}_{3} \mathrm{COOH}\end{array}$ & $\begin{array}{l}\text { I } 2,903 \\
\text { I } 2,943 \\
\text { I } 2,92 \text { I }\end{array}$ & I 2,922 \\
\hline
\end{tabular}

${ }^{1}$ Reaction chosen for determination of water equivalent of apparatus. 
It has been shown that the Dewar flask may be used successfully as a calorimeter for determining the heats of neutralization of acids and bases at widely different concentrations; heat radiation is very small, even when working considerably below room temperature, and results may be obtained which are concordant. By using but one vessel the acid and alkali acquire the same temperature and that temperature may be determined exactly. The working parts are simple, and if necessary can be made by a student of ordinary skill, thus making it both a convenient and reliable method for laboratory use in classes of physical and thermochemistry.

Laboratory of Physical Chemistry, University of Wisconsin, Madison, Ocioher, I9Io 